\title{
Determination of serum CRP, VEGF, Leptin, CK-MB, CA-15-3 and IL-6 levels for malignancy prediction in adnexal masses
}

\author{
Adneksiyel kitlelerde malignite prediksiyonunda tümör belirteci olarak serumda \\ CRP, VEGF, Leptin, CK-MB, CA-15-3, IL-6 bakilması
}

\author{
Serhat Şen ${ }^{1}$, Oğuzhan Kuru' ${ }^{1}$ Özgür Akbayır ${ }^{2}$, Hilal Oğuz ${ }^{3}$, Vildan Yasasever ${ }^{3}$, Sinan Berkman ${ }^{1}$ \\ 'Department of Obstetrics and Gynecology, Istanbul Faculty of Medicine, Istanbul University, Istanbul, Turkey \\ ${ }^{2}$ Department of Obstetrics and Gynecology, Kanuni Sultan Süleyman Research and Training Hospital, Istanbul, Turkey \\ ${ }^{3}$ Department of Basic Oncology, Institute of Oncology, İstanbul University, İstanbul, Turkey
}

\section{Abstract}

Objective: Investigation of serum markers which could be used in the malignancy prediction of adnexal masses.

Material and Methods: Vascular endothelial growth factor (VEGF), interleukin 6 (IL-6), leptin, C-reactive protein (CRP), creatine-kinaseMB (CK-MB) and cancer antigen 15-3 (CA 15-3) levels were determined prospectively in serum samples that were obtained from patients who underwent surgery for an adnexal mass and who were referred to Istanbul University, Faculty of Medicine, Department of Obstetrics and Gynecology, between 2009 and 2011, and then were compared with the serum samples of completely healthy outpatient patients as a control group. Based onto the ovarian cancer status, cases were divided into four groups: 13 patients were included in the early-stage malignant group, 12 patients were included in the advanced-stage malignant group, 25 in the benign group and 19 in the healthy control group. Patients with only epithelial ovarian cancer were included into the cancer group. Ethics Commitee approval was obtained for this study. The budget was supported by the Istanbul University Scientific Research Projects Unit.

Results: Results related with sensitivity, specificity, positive predictive value (PPV), negative predictive value (NPV) and odds ratio (OR), respectively, and the following values were calculated: $48 \%, 95 \%, 92 \%$, $59 \%$ and +OR 9.6 -OR 0.5 for CA; $15-3 ; 52 \%, 75 \%, 72 \%, 55 \%,+$ OR 2.08 -OR 0.64 for leptin; $72 \%, 70 \%, 75 \%, 66 \%$ 2.4-0.5 for IL-6; $24 \%, 80 \%, 60 \%$, $45 \%, 1.2-0.92$ for VEGF; $68 \%, 30 \%, 55 \%, 43 \%, 0.97-1.06$ for CRP; and $8 \%$, $70 \%, 25 \%, 38 \%, 026-1.31$ for CK-MB.

Conclusion: CA 15-3, IL-6, Leptin, VEGF and CRP were effective in the prediction of benign and malignant masses; however they may be more suitable in selected cases as they have a limited use because of their inadequate potential regarding sensitivity and specificity.

(J Turkish-German Gynecol Assoc 2011; 12: 214-9)

Key words: Adnexal masses, malignancy prediction, epithelial ovarian cancer, serum biomarkers

Received: 12 July, 2011

\section{Özet}

Amaç: Adneksiyel kitlelerde malignite ayrımında kullanılabilecek serum markerlarının araştırılması.

Gereç ve Yöntemler: İstanbul Üniversitesi İstanbul Tıp Fakültesi Kadın Hastalıkları ve Doğum Anabilim Dalı'nda 2009-2011 yılları arasında prospektif olarak, adneksiyel kitle endikasyonu ile opere olan hastalardan alınan serum örneklerinde vascular endotelial growth factor (VEGF), interlökin 6 (IL-6), leptin, C-reaktif protein (CRP), kreatin kinaz-MB (CK-MB) ile kanser antijeni 15-3 (CA 15-3) düzeyleri belirlendi ve kontrol grubu olan tamamen sağlıklı poliklinik hastalarının serum örnekleriyle karşılaştırıldı. Olgular over kanseri durumuna göre 4 grupta toplandi: 13 olgu erken evre malign, 12 olgu ileri evre malign, 25 olgu benign, 19 olgu sağlıklı kontrol grubunda yer aldı. Over kanseri grubunda sadece epitelyal over kanseri olan olgular çalışmaya dahil edildi. Çalışma için etik kurul onayı alındı ve bütçe ise İstanbul Üniversitesi Bilimsel Araştırma Projeleri Birimi tarafından desteklendi. Bulgular: Belirteçlerin duyarlılık, özgüllük, pozitif prediktif değer (PPD), negatif prediktif değer (NPD) ve odds ratio (OR) sonuçlarına bakıldığında CA 15-3 için sırasıyla \%48, \%95, \%92, \%59 ve +OR 9.6 -OR 0.5 ; leptin için sırasiyla \%52, \%75, \%72, \%55, +OR 2.08 -OR 0.64 ; IL-6 için \%72, \%70, \%75, \%66 2.4-0.5; VEGF için \%24, \%80, \%60, \%45, 1.2-0.92; CRP için \%68, \%30, \%55, \%43, 0.97-1.06; CK-MB için \%8, \%70, $\% 25, \% 38,026-1.31$ değerleri hesaplandı.

Sonuç: CA 15-3, IL-6, Leptin, VEGF ve CRP benign-malign over tümörü ayrımında etkin bulundu ancak duyarlılık ve özgüllükleri yeteri kadar kuvvetli olmadığı için rutinde kullanımı kısıtlı olup seçilmiş vakalarda kullanımı uygun olabilir.

(J Turkish-German Gynecol Assoc 2011; 12: 214-9)

Anahtar kelimeler: Adneksiyel kitleler, malignite prediksiyonu, epitelyal over kanseri, serum biomarkerları

Geliş Tarihi: 12 Temmuz 2010

Kabul Tarihi: 06 Eylül 2011

Address for Correspondence: Serhat Şen, Department of Obstetrics and Gynecology, İstanbul Faculty of Medicine, Istanbul University, İstanbul, Turkey Phone: +902124142000 e.mail: cerrahserhat@yahoo.com (C) Copyright 2011 by the Turkish-German Gynecological Education and Research Foundation - Available online at www.jtgga.org doi:10.5152/jtgga.2011.54 


\section{Introduction}

Ovarian cancer is the second most common and lethal gynecological cancer seen in women (1). The condition ranks in $5^{\text {th }}$ place in cancers among women. Ovarian cancers are listed in $4^{\text {th }}$ place for death due to cancer in women. In the U.S.A, more than 15.000 women die every year because of ovarian cancer (2). At the early stage, life expectancy can be as high as $90 \%$, but unfortunately only $19 \%$ of the patients can be diagnosed during the early stage of the disease (3). Most of the patients are diagnosed at the advanced stage when consequently their life expectancy falls below 30\%. Early ovarian cancer may not cause obvious symptoms. Ovarian cancer is generally diagnosed when considerable abdominal fluid is observed (at this stage the tumor can be at an advanced stage) or when a mass in the pelvic region is found by the imaging methods (ultrasonography, magnetic resonance imaging, computerized tomography). However, these imaging methods may not be capable of having a high specificity to differentiate benign and malignant tumors. Furthermore, additional surgical interventions may be required when an abnormal image is determined. Consequently, imaging methods may not be reliable in detecting ovarian cancers at the early stage and can be variable (4).

However, there are no biomarkers that are known to diagnose ovarian cancer. Cancer antigen 125 (CA-125) was frequently employed to help the diagnosis of ovarian cancer, but it was basically approved to determine the recurrent disease and monitor response to the therapy (5-7). The sensitivity of CA-125 in detecting an early stage ovarian cancer varies between $29 \%$ $75 \%$. Additionally, CA-125 level may also increase during certain circumstances such as endometriosis, pregnancy, menstruation, cardiac failure and cirrhosis, which are considered as normal or benign conditions. In a recent study, it was observed that an abnormal level of CA-125 failed to indicate the presence of a cancer in $86 \%$ of the cases, whereas the mentioned level returned to normal within 3-6 months (8). Today, we still require good biomarkers which can be used in the diagnosis of ovarian cancer.

\section{Materials and Methods}

Blood samples were collected from patients who were operated on due to an adnexal mass and from outpatient patients who were completely healthy as a control group, prospectively between 2009-2011 at the Istanbul University, Istanbul Medical Faculty Department of Obstetrics and Gynecology. Blood samples were kept 30 minutes in room temperature and then were centrifuged for 10 minutes at $4000 \mathrm{rpm}$. Separated serums were stored at $-80^{\circ} \mathrm{C}$ until the number of tests were completed.

Serum C-reactive protein (CRP) levels of patients and control groups were determined by a Toshiba Accute auto-analyzer and immuno-turbidimetric method, while creatine-kinase-MB (CK-MB) and cancer antigen 15-3 (CA 15-3) levels were determined with an Abbott Axsym device and micro-particle enzyme immune-assay (MEIA) method. Vascular endothelial growth factor (VEGF), interleukin 6 (IL-6) and leptin levels were determined by a dual antibody sandwich enzyme immune-assay (ELISA) method.
All pathological samples were examined and diagnosed by 3 specialists from Istanbul Faculty of Medicine, Department of Gynecopathology. The FIGO surgical staging system was used in the staging of ovarian cancer. Histopathological classification was carried out according to the World Health Organization. Serum samples obtained from patients were examined at the Istanbul University, Institute of Oncology, Department of Cancer Biochemistry.

Patients were classified in four groups: Early Stage (Stage 1 and 2), Advanced Stage (Stage 3 and 4), benign ovarian tumors and healthy control groups. Only patients with epithelial ovarian cancer were included into the cancer groups. Patients were distributed into appropriate groups according to their postoperative diagnosis and surgical stage. Accordingly, 13 patients were included in the early stage malignant group, 12 patients in the advanced stage malignant group, 25 patients in the benign group and 19 patients in the healthy (control) group. The control group was used to determine the cut-off values of markers which did not have a cut-off value. The upper limit value was estimated by an average +2 standard deviation formula at the 95\% confidence interval. Demographic similarities of patients' data were compared by the student's t-test. Statistical power analysis was also made. Because of time limitation and inadequate cases, only $70 \%$ statistical power was reached with 25 ovarian cancer cases.

A comparison was made by the student's t-test and MannWhitney U-test to determine if there was a difference between the mean value of each tumor marker in the groups. The Wilcoxon method was used to calculate the value of markers regarding the difference between benign and malignant tumors. However, the number of patients with a malignant tumor in the study group was low and therefore ANOVA testing was not applied. Instead, the Kruskal-Wallis test was used to determine the relationship of the stage of the tumor of each parameter. The correlation between markers in malignant tumors was determined by a Pearson correlation analysis. A linear regression study was carried out on markers which showed significant correlation. Cut-off values were obtained as the following:

CA 15-3: 0-30 U/mL

CRP: $5 \mathrm{mg} / \mathrm{dl}$

Cut-off values were obtained from the healthy control group for CK-MB, IL-6, VEGF and Leptin. The following values were estimated: $9.65 \mathrm{pg} / \mathrm{mL}$ for IL-6, $201 \mathrm{pg} / \mathrm{mL}$ for VEGF, $1.225 \mathrm{pg} / \mathrm{mL}$ for Leptin and $0.9 \mathrm{ng} / \mathrm{mL}$ for CK-MB. Ethics Commitee approval was obtained for this study. The budget was supported by the Istanbul University Scientific Research Projects Unit.

\section{Results}

Clinical characteristics of patients showed that the most frequent histological diagnosis was serous carcinoma; $20 \%$ of the patients were at the early stage malignant, $18.75 \%$ at the advanced stage malignant, $31 \%$ at the benign ovarian tumor and $29.6 \%$ were the healthy control group. The distribution of these ratios are displayed in Table 1. Average age and parity were found statistically significant at higher levels in the 
advanced stage cancer group, respectively 49.6 and 3.4 when compared to other groups $(\mathrm{p}<0.05)$ (Table 2$)$.

Sensitivity, specificity, positive predictive value (PPV), negative predictive value (NPV) and odds ratio (OR) for CA 15-3, respectively, were 48\%, 95\%, 92\%, 59\% and +OR 9.6 -OR 0.5.

Sensitivity, specificity, PPV, NPV and OR for IL-6, respectively, were $72 \%, 70 \%, 75 \%, 66 \%, 2.4-0.5$.

Table 1. Clinical characteristics of patients

\begin{tabular}{|c|c|}
\hline & Number of Patients (\%) \\
\hline Ovarian Cancer Groups & \\
\hline Early (I and II) & $13(20.3 \%)$ \\
\hline Advanced (III and IV) & $12(18.75 \%)$ \\
\hline Benign Ovarian Tumor & $25(31.25 \%)$ \\
\hline Healthy (control) group & $19(29.6 \%)$ \\
\hline Histology & \\
\hline Serous carcinoma & $12(17.39 \%)$ \\
\hline Endometrioid carcinoma & $5(7.24 \%)$ \\
\hline Mucinous carcinoma & $6(8.69 \%)$ \\
\hline Mixed carcinoma & $2(2.89 \%)$ \\
\hline Endometrioma & $9(13.04 \%)$ \\
\hline Serous cystadenoma & $7(10.14 \%)$ \\
\hline Mucinous cystadenoma & $4(5.79 \%)$ \\
\hline Teratoma & $3(4.3 \%)$ \\
\hline Fibrotectoma & $2(2.8 \%)$ \\
\hline
\end{tabular}

Table 2. Demographic data of the groups

\begin{tabular}{|c|c|c|c|c|}
\hline Group & & Year & Gravida & Parity \\
\hline \multirow[t]{5}{*}{ Early stage } & $\mathrm{N}$ & 13 & 10 & 10 \\
\hline & Mean & 44.6 & 3.8 & 2.1 \\
\hline & Standard deviation & 4.45 & 1.1 & 0.6 \\
\hline & Minimum & 25 & 0 & 0 \\
\hline & Maximum & 62 & 6 & 4 \\
\hline \multirow[t]{5}{*}{ Advanced Stage } & $\mathrm{N}$ & 12 & 10 & 10 \\
\hline & Mean & 49.6 & 4.2 & 3.4 \\
\hline & Standard deviation & 6.4 & 1.4 & 0.8 \\
\hline & Minimum & 36 & 0 & 0 \\
\hline & Maximum & 66 & 10 & 6 \\
\hline \multirow[t]{5}{*}{ Benign } & $\mathrm{N}$ & 25 & 19 & 19 \\
\hline & Mean & 41.6 & 3.5 & 2.1 \\
\hline & Standard deviation & 10.3 & 1.3 & 1.0 \\
\hline & Minimum & 23 & 0 & 0 \\
\hline & Maximum & 68 & 10 & 7 \\
\hline \multirow[t]{5}{*}{ Control } & $\mathrm{N}$ & 19 & 17 & 16 \\
\hline & Mean & 40.1 & 3.4 & 2.3 \\
\hline & Standard deviation & 8.9 & 1.4 & 1.1 \\
\hline & Minimum & 27 & 0 & 0 \\
\hline & Maximum & 57 & 13 & 12 \\
\hline
\end{tabular}

Sensitivity, specificity, PPV, NPV and OR for leptin, respectively, were 52\%, 75\%, 72\%, 55\%, +OR 2.08 -OR 0.64.

Sensitivity, specificity, PPV, NPV and OR for VEGF, respectively, were $24 \%, 80 \%, 60 \%, 45 \%, 1.2-0.92$.

Sensitivity, specificity, PPV, NPV and OR for CRP, respectively, were $68 \%, 30 \%, 55 \%, 43 \%, 0.97-1.06$.

Sensitivity, specificity, PPV, NPV and OR for CK-MB, respectively, were $8 \%, 70 \%, 25 \%, 38 \%, 0.26-1.31$.

Accordingly, it was significant that CA 15-3 was the most specific and IL-6 the most sensitive markers (Table 3). Pearson correlation analysis displayed a correlation coefficient value of 0.193 among these two values, while $p$ value was 0.013 which was considered statistically significant. On the other hand, leptin with relatively high positive and negative predictive ratios, showed a significant correlation with CA 15-3 (correlation coefficient: $0.185, \mathrm{p}=0.020$ ) (Table 4).

The logistic regression analysis of CA 15-3 and IL-6 was found more sensitive in the malignancy prediction of ovarian tumors when used concomitantly, but failed to reach a level which can be considered as significant.

Among tumor markers, CA 15-3, IL-6 and CRP showed a significant increase in the malignant tumor group, while VEGF and Leptin displayed a significant increase both in the malignant and benign tumor groups when compared with the control group (Table 5). Also, a statistical difference was found in CA 15-3, IL-6 and CRP levels between the early stage and the advanced stage groups. However, these markers were not capable of making a prediction related with stage differentiation (Table 6).

We have analysed the success of these markers by the Wilcoxon rank test to understand what parameter they were successful in detecting an early stage ovarian tumor, and after separate measurements, it was concluded that CA 15-3, IL-6, Leptin and VEGF were suitable to be used in the early stage differentiation of ovarian tumors $(\mathrm{p}<0.05)$ (Table 7). Also, a ROC curve (Figure 1) was determined. It was also concluded that CA 15-3, IL-6 and CRP were useful in differentiating ovarian cancers from benign tumors (Table 8). The sensitivity, specificity, PPV and NPV of these markers must be considered.

\section{Conclusion}

There is no ideal model for scanning of an ovarian cancer nor is there an approved clinical test for diagnosis at the early stage. Currently, early stage sensitivity of the many biomarkers which were used to clinically diagnose ovarian cancer, is low (9). At present CA 125 is the most reliable serum marker in ovarian cancer but its role in scanning the disease is challengeable. High CA 125 levels can be encountered in 30\% during Stage I and $90 \%$ during the advanced stage (10). Additionally, mucinous ovarian tumors may secrete a lesser degree of CA 125 when compared to non-mucinous type ovarian cancers (11). Many researchers agree that a minimum 10\% positive predictive value must be achieved in the scanning process of an ovarian cancer. To attain this value, it may be necessary to reach a minimum ratio of $99.6 \%$ specificity. Nevertheless, specificity of CA 125 is considerably lower than this value (12-14). Therefore, 
Table 3. Sensitivity, specificity, positive predictive value (PPV), negative predictive value (NPV) of 6 biomarkers

\begin{tabular}{|l|c|c|c|c|c|}
\hline Marker & Cut-off value & Sensitivity (\%) & Specificity (\%) & PPV (\%) & NPV (\%) \\
\hline CA 15-3 & $30 \mathrm{U} / \mathrm{mL}$ & 48 & 95 & 92 & 59 \\
\hline IL-6 & $9.65 \mathrm{pg} / \mathrm{mL}$ & 72 & 70 & 75 & 66 \\
\hline Leptin & $1225 \mathrm{pg} / \mathrm{mL}$ & 52 & 75 & 72 & 55 \\
\hline VEGF & $201 \mathrm{pg} / \mathrm{mL}$ & 24 & 80 & 60 & 45 \\
\hline CRP & $5 \mathrm{mg} / \mathrm{dl}$ & 68 & 30 & 55 & 43 \\
\hline CK-MB & $0.9 \mathrm{ng} / \mathrm{mL}$ & 8 & 70 & 25 & 38 \\
\hline
\end{tabular}

Table 4. Pearson's correlation coefficients of 6 biomarkers

\begin{tabular}{|c|c|c|c|c|c|c|}
\hline & CA 15-3 & IL-6 & Leptin & VEGF & CRP & CK-MB \\
\hline \multicolumn{7}{|l|}{ CA 15-3 } \\
\hline $\mathrm{CC}$ & 1 & $0.193^{*}$ & $-0.185^{\gamma}$ & 0.131 & 0.095 & 0.024 \\
\hline$p$ value & & 0.013 & 0.020 & 0.087 & 0.120 & 0.95 \\
\hline \multicolumn{7}{|l|}{ IL-6 } \\
\hline $\mathrm{CC}$ & 0.193 & 1 & -0.108 & 0.101 & 0.126 & 0.031 \\
\hline$p$ value & 0.013 & & 0.091 & 0.130 & 0.130 & 0.87 \\
\hline \multicolumn{7}{|l|}{ Leptin } \\
\hline $\mathrm{CC}$ & -0.185 & -0.108 & 1 & -0.113 & -0.098 & 0.28 \\
\hline$p$ value & 0.020 & 0.091 & & 0.081 & 0.24 & 0.98 \\
\hline \multicolumn{7}{|l|}{ VEGF } \\
\hline $\mathrm{CC}$ & 0.131 & 0.101 & -0.113 & 1 & 0.361 & 0.020 \\
\hline$p$ value & 0.087 & 0.112 & 0.081 & & 0.361 & 0.91 \\
\hline \multicolumn{7}{|l|}{ CRP } \\
\hline $\mathrm{CC}$ & 0.095 & 0.126 & -0.098 & 0.071 & 1 & 0.076 \\
\hline$p$ value & 0.120 & 0.130 & 0.24 & 0.361 & & 0.210 \\
\hline \multicolumn{7}{|l|}{ CK-MB } \\
\hline $\mathrm{CC}$ & 0.024 & 0.031 & 0.28 & 0.020 & 0.076 & 1 \\
\hline $\mathrm{p}$ value & 0.85 & 0.87 & 0.88 & 0.91 & 0.210 & \\
\hline
\end{tabular}

to achieve this purpose; various biomarkers must be used synchronically $(15,16)$.

Because of the heterogenic structure of the ovarian cancer, a single biomarker may not be capable of covering the entire types and stages. Use of multiple biomarkers may be necessary to determine ovarian cancer at an early stage (17). Gorelik et al. were successful in differentiating 44 early stage ovarian cancers in the serum samples of 45 healthy women by using a combination of IL-6, IL-8, VEGF, EGF and CA 125 biomarkers, where a ratio of $84 \%$ for sensitivity and $95 \%$ for specificity were obtained (18). In a study performed by Zhang et al. early stage ovarian cancer was diagnosed with $72 \%$ sensitivity after CA 125 , CA 72-4, CA 15-3 and M-CSF biomarkers were used in combination according to an artificial estimation system (19). Similarly, Skates et al. determined early stage ovarian cancer with a $98 \%$ specificity and $75 \%$ sensitivity by using a CA 125, CA 15-3, CA 72-4 and M-CSF combination (20). Additionally, different biochemical and ultrasonographic parameters can be used to carry out a differentiated diagnosis of adnexal masses based on logistic regression models (21). In a study performed by Woolas et al.
Table 5. Comparison of levels of tumor markers among the groups (mean \pm standard deviation)

\begin{tabular}{|l|c|c|c|}
\hline Tumor marker & $\begin{array}{c}\text { Ovarian } \\
\text { Cancer } \mathbf{n = 2 5}\end{array}$ & $\begin{array}{c}\text { Benign ovarian } \\
\text { tumor } \mathbf{n = 2 5}\end{array}$ & $\begin{array}{c}\text { Con trol } \\
\mathbf{n = 1 9}\end{array}$ \\
\hline CA 15-3 & $61.3 \pm 14^{*}$ & $13.86 \pm 7.1$ & $15.2 \pm 5.1$ \\
\hline IL-6 & $70 \pm 11.0^{*}$ & $26 \pm 7.7$ & $26.5 \pm 8.4$ \\
\hline Leptin & $745.5 \pm 39^{*}$ & $862.11 \pm 41.9^{\gamma}$ & $941 \pm 28.4$ \\
\hline VEGF & $162.2 \pm 10.7^{*}$ & $142.2 \pm 12^{\gamma}$ & $96.4 \pm 9.2$ \\
\hline CRP & $16 \pm 1.5^{*}$ & $11.8 \pm 1.3$ & $11.6 \pm 1.1$ \\
\hline CK-MB & $0.63 \pm 0.01$ & $0.74 \pm 0.04$ & $0.58 \pm 0.02$ \\
\hline
\end{tabular}

* Statistical difference was determined in the cancer group compared with the control group, $\mathrm{p}<0.05$. (Negative correlation was also observed in the leptin levels), ${ }^{\gamma}$ Statistical difference was determined in the benign ovarian tumor group compared with the control group, $\mathrm{p}<0.05$

effectiveness was enhanced by combining 8 different tumor markers (MCSF, OVX1, LASA, CA 15-3, CA 72-4, CA 19-9, CA 54 and CA 61) in 492 patients, where 192 of these patients had ovarian cancer. The single sensitivity and specificity of CA 125 
was found as $78.1 \%$ and $76.8 \%$ respectively. Different combinations were used in logistic regression analysis where sensitivity achieved a ratio of $90.6 \%$ and a specificity of $93.2 \%$ where this improvement can be considered as satisfactory (22).

Table 6. Deviation of significant tumor markers among the stages (mean \pm standard deviation)

\begin{tabular}{|l|c|c|}
\hline Tumor Marker & $\begin{array}{c}\text { Stage I and II } \\
\mathbf{n}=\mathbf{1 3}\end{array}$ & $\begin{array}{c}\text { Stage III and IV } \\
\mathbf{n}=\mathbf{1 2}\end{array}$ \\
\hline CA 15-3 & $23.21 \pm 2.6$ & $102.7 \pm 19.7^{*}$ \\
\hline IL-6 & $31.1 \pm 4.4$ & $113.3 \pm 14.3 *$ \\
\hline Leptin & $731 \pm 38.9$ & $761.2 \pm 39.3$ \\
\hline VEGF & $178.9 \pm 13.6$ & $144.9 \pm 6.6$ \\
\hline CRP & $7.5 \pm 0.6$ & $25.5 \pm 1.7 *$ \\
\hline $\begin{array}{l}\text { *statistical difference was encountered between the early stage and } \\
\text { the advanced stage groups p<0.05 }\end{array}$ \\
\hline
\end{tabular}

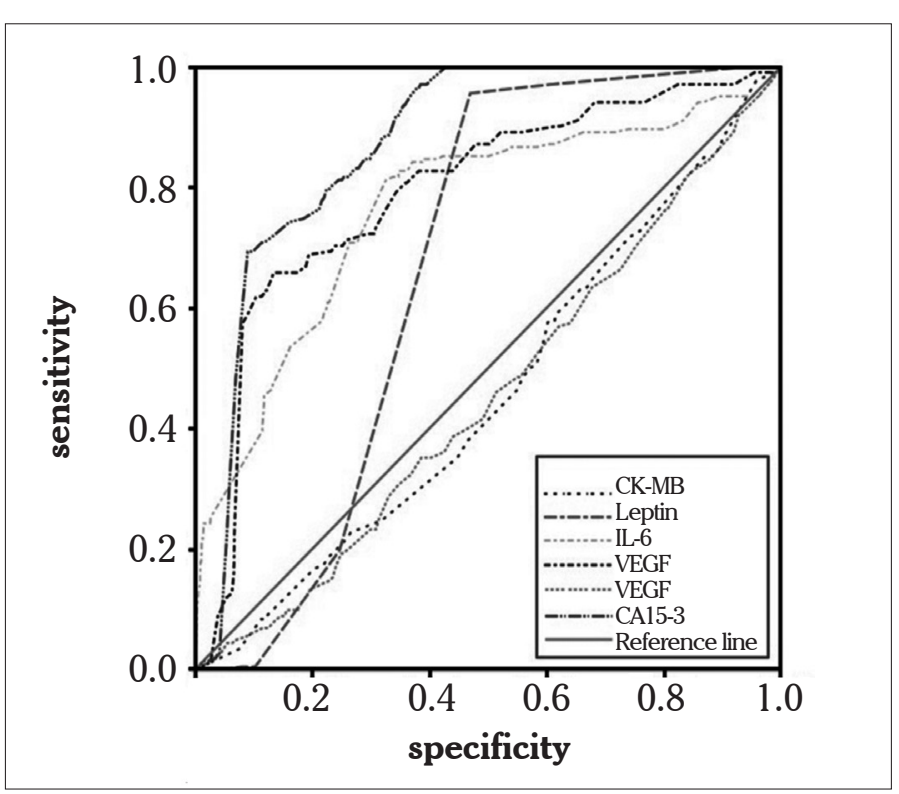

Figure 1. ROC Curve
In our study, CA 15-3 was found to be the most specific and IL-6 the most sensitive marker. Pearson correlation analysis demonstrated that concomitant use of CA 15-3 and IL-6 in logistic regression analysis, as these markers display a positive correlation, could be more sensitive in the differentiation of benignmalignant ovarian tumors, but these findings were unable to reach a significant level. In a similar study, CA 15-3 showed a lower sensitivity ratio, while higher specificity in the malignancy prediction of adnexal masses was found (23).

Gil Mor et al. found that 4 biomarkers (leptin, prolactin, osteopontin, insulin-like growth factor-II) may not be useful alone in the prediction of malignancy, but the combination of these four markers may be effective in the prediction of an early stage ovarian cancer as they possess a $95 \%$ ratio of sensitivity, $95 \%$ ratio of specificity, 95\% ratio of PPV and 94\% ratio of NPV (15). In our study, leptin alone was also found effective in the prediction of early stage ovarian cancer. However its $52 \%$ ratio of sensitivity and $75 \%$ ratio of specificity may cause a handicap for clinical significance.

The most comprehensive study in the literature was carried out by Bertenshaw et al. where a total number of 204 molecules were investigated. Among these molecules, 104 antibodies, 44 autoimmune markers, and 56 infection molecules were significant. Also, levels of 77 biomarkers were found different and the most significant molecules were CA 125, CRP, EGFR, IL-10, IL-8, CTGF, haptoglobulin, and TIMP-1. Excluding CA 125, no specificity higher than $80 \%$ was determined in any of the mentioned markers. The 8 markers herein mostly consist of inflammation markers and acute phase reactants. CRP level was found significantly increased and was accepted as the second most determinative biomarker. Increased IL-6 level was stated to be responsible for the high correlation of CRP level. The inflammatory response and the active state of the tumor, may prepare a suitable environment for angiogenesis and metastasis, as there is also some information that it may contribute to the progression of the cancer $(24,25)$. In our study CRP and IL-6 levels were also found significant in the scanning of ovarian cancer (Table 8). Angiogenesis plays a significant role in the tumorigenesis. Bertenshaw et al. (25) showed a significant increase in the VEGF level, which is a

Table 7. $p$ values of the markers for the detection of early-stage ovarian cancer

\begin{tabular}{|l|c|c|c|c|c|c|}
\hline & CA 15-3 & IL-6 & Leptin & VEGF & CRP & CK-MB \\
\hline p value & 0.044 & 0.038 & 0.001 & 0.0003 & 0.213 & 0.762 \\
\hline
\end{tabular}

Table 8. Analysis of the ROC Curve

\begin{tabular}{|c|c|c|c|c|}
\hline Marker & $\begin{array}{l}\text { Area Under the } \\
\text { Curve (AUC) }\end{array}$ & Standard Deviation & p value & 95\% confidence \\
\hline CA $15-3$ & $0.861 *$ & 0.009 & 0.000 & $0.810-0.823$ \\
\hline IL-6 & $0.785^{*}$ & 0.016 & 0.000 & $0.751-0.814$ \\
\hline Leptin & 0.063 & 0.012 & 0.000 & $0.638-0.681$ \\
\hline VEGF & 0.458 & 0.022 & 0.040 & $0.404-0.462$ \\
\hline CRP & $0.761 *$ & 0.021 & 0.000 & $0.718-0.796$ \\
\hline CK-MB & 0.451 & 0.023 & 0.051 & $0.398-0.458$ \\
\hline
\end{tabular}


potent angiogenetic factor. In our study, a similar increase was also detected in the VEGF levels of the ovarian cancer group. We found higher ratios of mean age and higher parity values in patients included in the advanced stage ovarian cancer group when compared with other groups $(p<0.05)$. Even though this finding is compatible with the information in the literature related with the increased risk of ovarian cancer due to higher age, it is contrary to the information that ovarian cancer risk may decrease when parity is increased (26-28).

Although a ROC curve was created in this study, the number of early stage ovarian cancer cases in the sample group was fewer than expected and could cause a bias for our study. Information was obtained from a limited number of patients and therefore clinical significance is readily decreased. However, according to the current data, CA 15-3, IL-6 , leptin, VEGF and CRP were found effective in the differentiation process of benign-malignant ovarian tumors. Parameters such as sensitivity and specificity alone were not as effective as estimated, and may not be convenient for routine applications, but differential diagnosis can be used in solving problematic cases.

There is a strong need for large-scale serial studies which may confirm and strengthen the findings of this study. Additionally, this study could be an important indicator that it may not be suitable to use CK-MB as a biomarker in future studies.

\section{Conflict of interest}

The budget was supported by the Istanbul University, Scientific Research Projects Unit.

\section{References}

1. American Cancer Society. Cancer facts and figures 2007. Atlanta: American Cancer Society; 2007.

2. Cannistra SA. Cancer of the ovary. N Engl J Med 1993; 329: 1550-9. [CrossRef]

3. Res LAG, Melbert D, Krapcho M, et al. SEER cancer statistics review, 1975-2004. Bethesda (MD): National Cncer Institute; 2007. Based on Novermber 2006 SEER data submission, posted to the SEER web site.

4. Teneriello MG, Park RC. Early detection of ovarian cancer. CA Cancer J Clin 1995; 45: 71-87. [CrossRef]

5. Klug TL, Bast RC Jr, Niloff JM, Knapp RC, Zurawski VR Jr. Monoclonal antibody immunoradiometric assay for an antigenic determinant (CA-125) associated with human epithelial ovarian carcinomas. Cancer Res 1984; 44: 1048-53.

6. Rose PG, Fusco N, Fluellen L, Rodriguez M. Second-line therapy with paclitaxel and carboplatin for recurrent disease following firstline therapy with paclitaxel and platinum in ovarian or peritoneal carcinoma. J Clin Oncol 1998; 16: 1494-7.

7. Schilthuis MS, Aalders JG, Bouma J, Kooi H, Fleuren GJ, Willemse PH, et al. Serum CA-125 levels in epithelial ovarian cancer: relation with findings at second-look operations and their role in the detection of tumour recurrence. Br J Obstet Gynaecol 1987; 94: 202-7. [CrossRef]

8. Oei, AL, Massuger LF, Bulten J, et al. Surveillance of women at high risk for hereditary ovarian cancer is inefficient. Br J Cancer 2006; 94: 814-9. [CrossRef]

9. Jacobs U, Menon U. Progress and challenges in screening for early detection of ovarian cancer. Mol Cell Proteomics 2004; 3: 355-66. [CrossRef]

10. Berek JS, Bark JR RC. The CA 125 tumor associated antigen: a review of the literature. Hum Repr 1989; 4: 1-12.
11. Gadducci A, Ferdeghini M, Prontera C, Moretti L, Mariani G, Bianchi $\mathrm{R}$, et al. The concomitant determination of different tumor markers in patients with epithelial ovarian cancer and benign ovarian masses: relevance for differential diagnosis. Gynecol Oncol 1992; 44: 147-54. [CrossRef]

12. Gezginç K, Çelik Ç, Bala A, Acar A, Çiçek N, Akyürek C. Comparison of ultrasonography and Ca-125 in differential diagnosis of malign adnexial masses. J Turkish-German Gynecol Assoc 2003; 4: 42-5.

13. Tanriverdi HA, Sade H, Akbulut V, Barut A, Bayar Ü. Clinical and ultrasonographic evaluation of pelvic masses. J Turkish-German Gynecol Assoc 2007; 8: 67-70.

14. Jacobs IJ, Oram DH, Bast RC Jr. Strategies for improving the specificity of screening for ovarian cancer with tumor-associated antigens CA 125, CA 15-3, and TAG 72.3. Obstet Gynecol 1992; 80: 396-9.

15. Mor G, Visintin I, Lai Y, Zhao H, Schwartz P, Rutherford T, et al. Serum protein markers for early detection of ovarian cancer. Proc Nati Acad Sci USA 2005; 102: 7677-82. [CrossRef]

16. Zhang Z, Bast RC Jr, Yu Y, Li J, Sokoll LJ, Rai AJ, et al. Three biomarkers identified from serum proteomic analysis for the detection of early stage ovarian cancer. Cancer Res 2004; 64: 5882-90. [CrossRef]

17. Kingsmore SF. Multiplexed protein measurement: technologies and applications of protein and antibody arrays. Nat Rev Drug Discov 2006; 5: 310-20. [CrossRef]

18. Gorelik E, Landsittel DP, Marrangoni AM, Modugno F, Velikokhatnaya L, Winans MT, et al. Multi-plexed immunobead-based cytokine profiling for early detection of ovarian cancer. Cancer Epidemiol Biomarkers Prev 2005; 14: 981-7. [CrossRef]

19. Zhang Z, Yu Y, Xu F, Berchuck A, van Haaften-Day C, Havrilesky LJ, et al. Combining multiple serum tumor markers improves detection of stage I epithelial ovarian cancer. Gynecol Oncol 2007; 107: 526-31. [CrossRef]

20. Skates SJ, Horick N, Yu Y, Xu FJ, Berchuck A, Havrilesky LJ, et al. Pre-operative sensitivity and specifity for early stage ovarian cancer when combining CA 125, CA 15-3, CA72-4 and M-CSF using mixtures of multivariate normal distributions. J Clin Oncol 2004; 22: 4059-66. [CrossRef]

21. Timmerman D, Bourne TH, Tailor A, Collins WP, Verrelst $H$, Vandenberghe $\mathrm{K}$, et al. A comparison of methods for preoperative discrimination between malignant and benign adnexal masses: the development of a new logistic regression model. Am J Obstet Gynecol 1999; 181: 57-65. [CrossRef]

22. Woolas RP, Conaway MR, Xu F, Jacobs IJ, Yu Y, Daly L, et al. Combination of multiple serum markers are superior to individual assays for discriminating malignant from benign pelvic masses. Gynecol Oncol 1995; 59: 111-6. [CrossRef]

23. Makar AP, Kristensen GB, Kaern J, Børmer OP, Abeler VM, Tropé CG. Prognostic value of pre- and post-operative serum CA 125 levels in ovarian cancer: new aspects and multivariate analysis. Obstet Gynecol 1992; 79: 1002-10.

24. Marx J. Cancer biology. All in the stroma: Cancer's Cosa Nostra. Science 2008; 320: 38-41.

25. Bertenshaw GP, Yip P, Seshaiah P, Zhao J, Chen TH, Wiggins WS, et al. Multianalyte profiling of serum antigens and autoimmune and infectious disease molecules to identify biomarkers dysregulated in epithelial ovarian cancer. Cancer Epidemiol Biomarkers Prev 2008; 17: 2872-81. [CrossRef]

26. Runnebaum IB, Stickeler E. Epidemiological and molecular aspects of ovarian cancer risk. J Cancer Res Clin Oncol 2001; 127: 73-9. [CrossRef]

27. Yancik R, Ries LG, Yates JW. Ovarian cancer in the elderly: an analysis of Surveillance, Epidemiology and End Results Program data. Am J Obstet Gynecol 1986; 154: 639-47.

28. Purdie DM, Bain CJ, Siskind V, Webb PM, Green AC. Ovulation and risk of epithelial ovarian cancer. Int J Cancer 2003; 104: 228-32 [CrossRef] 